\title{
Genetic and metabolic comparison of orthotopic and heterotopic patient-derived pancreatic-cancer xenografts to the original patient tumors
}

\author{
Eunsung Jun ${ }^{1,2}$, Seung-Mo Hong ${ }^{3}$, Hyun Ju Yoo ${ }^{4}$, Moon-Bo Kim ${ }^{5}$, Ji Sun Won ${ }^{1}$, \\ Soyeon $\mathrm{An}^{3}$, In Kyong Shim ${ }^{6}$, Suhwan Chang ${ }^{2}$, Robert M. Hoffman ${ }^{7,8}$ and Song \\ Cheol Kim ${ }^{1}$ \\ ${ }^{1}$ Division of Hepato-Biliary and Pancreatic Surgery, Department of Surgery, University of Ulsan College of Medicine and Asan \\ Medical Center, Seoul, South Korea \\ ${ }^{2}$ Department of Biomedical Sciences, University of Ulsan College of Medicine, Seoul, South Korea \\ ${ }^{3}$ Department of Pathology, University of Ulsan College of Medicine and Asan Medical Center, Seoul, South Korea \\ ${ }^{4}$ Department of Convergence Medicine, Asan Institute for Life Sciences, University of Ulsan College of Medicine and Asan \\ Medical Center, Seoul, South Korea \\ ${ }^{5}$ MetaBio Inc., Gangdong-Gu, Seoul, South Korea \\ ${ }^{6}$ Asan Institute for Life Science, University of Ulsan College of Medicine and Asan Medical Center, Seoul, South Korea \\ ${ }^{7}$ Department of Surgery, University of California, San Diego, CA, USA \\ ${ }^{8}$ AntiCancer Inc., San Diego, CA, USA \\ Correspondence to: Song Cheol Kim, email: drksc@amc.seoul.kr \\ Robert M. Hoffman, email: all@anticancer.com
}

Keywords: pancreatic cancer; patient-derived orthotopic xenograft PDOX; patient-derived heterotopic xenograft PDHX; homology; heterogeneity

Received: September 16, 2017 Accepted: October 13, $2017 \quad$ Published: December 21, 2017

Copyright: Jun et al. This is an open-access article distributed under the terms of the Creative Commons Attribution License 3.0 (CC BY $3.0)$, which permits unrestricted use, distribution, and reproduction in any medium, provided the original author and source are credited.

\section{ABSTRACT}

Tumors from 25 patients with pancreatic cancer were used to establish two patient-derived xenograft (PDX) models: orthotopic PDX (PDOX) and heterotopic (subcutaneous) PDX (PDHX). We compared gene expression by immunohistochemistry, single-nucleotide polymorphism (SNP), DNA methylation, and metabolite levels. The 4 cases, of the total of $\mathbf{1 3}$ in which simultaneous PDHX \& PDOX models were established, were randomly selected. The molecular-genetic characteristics of the patient's tumor were well maintained in the two PDX models. SNP analysis demonstrated that both groups were more than $\mathbf{9 0 \%}$ identical to the original patient's tumor, and there was little difference between the two models. DNA methylation of most genes was similar among the two models and the original patients tumor, but some gene sets were hypermethylated the in PDOX model and hypomethylated in the PDHX model. Most of the metabolites had a similar pattern to those of the original patient tumor in both PDX tumor models, but some metabolites were more prominent in the PDOX and PDHX models. This is the first simultaneous molecular-genetic and metabolite comparison of patient tumors and their tumors established in PDOX and PDHX models. The results indicate high fidelity of these critical properties of the patient tumors in the two models.

\section{INTRODUCTION}

Patient-derived xenografts (PDX) models of cancer have demonstrated important utility for the study of the mechanism of cancer, novel drug discovery and evaluation and personalized, precision medicine $[1,2]$.

There are two major types of PDX models: the orthotopic model, termed patient-derived orthotopic xenograft (PDOX) and a heterotopic model with 
subcutaneous implantation termed patient-derived heterotopic xenograft (PDHX).

Toward the goal of precision, personalized oncology, our laboratory pioneered the patient-derived orthotopic xenograft (PDOX) nude mouse model with the technique of surgical orthotopic implantation (SOI), including pancreatic [3-8], breast [8], ovarian [9], lung [10], cervical $[11,12]$, colon [13-15], stomach [16], sarcoma [17-28] and melanoma [29-33].

Our laboratories have focused on patient-derived mouse models of pancreatic cancer [3-8].

To effectively use pancreatic cancer patientderived xenograft (PDX) models in translational research, successful PDX engraftment of surgical specimens in immune-deficient mice is needed. In our previous study, a total of 102 patients underwent pancreatic cancer resection. Tumor tissue from all patents was implanted subcutaneously into mice and tumor engraftment and growth in mice were determined. Multivariate analysis showed that tumor size of more than $3.5 \mathrm{~cm}$ in the patient was a significant factor related to successful PDX engraftment. In contrast, there was no correlation of engraftment with surgical procedure, time needed to remove the specimen, tumor differentiation, lymph node metastasis, and protein expression of $\mathrm{p} 53$, receptor tyrosine-protein kinase erbB-2 (C-erbB-2), or deleted in pancreatic carcinoma locus 4 (DPC4) [34].

Formalin-fixed, paraffin-embedded (FFPE) specimens from pancreatic cancer patients were used for next generative sequencing (NGS) of DNA. This technology was applied to orthotopic and heterotopic pancreatic cancer models. The expression of genes PEAK1 and MST1R differed by over 100-fold in the two types of models [35].

Our goal in the present study was to further compare the molecular-genetic and metabolic characteristics of PDOX and PDHX models and determine if the characteristics of the original patient tumors were maintained in the models. Toward this goal, PDOX and PDHX models were established simultaneously using the same patient tumor in a series of 25 patients. We compared how similar the two models were to the original patient tumor, and to each other.

\section{RESULTS}

\section{Establishment and characteristics of PDOX and PDHX mouse models}

From January 2015 to December 2015, tumors were collected from 25 pancreatic cancer patients undergoing surgery for pancreatic cancer and used for establishing simultaneous PDHX and PDOX models in NSG mice. The average age of all patients was 61.8 years. Nineteen of the 25 patients $(76 \%)$ had undergone pancreaticoduodenectomy with a mean tumor size of $3.35 \mathrm{~cm}$. All patients were diagnosed at stage $\mathrm{T} 3$, and 20 patients $(80 \%)$ had lymph node metastasis at diagnosis. Eighteen patients $(72 \%)$ had p53 inactivation, 7 patients $(28 \%)$ had receptor tyrosine-protein kinase erbB-2(c-erbB-2) overexpression, and 11 patients (44\%) showed deleted in pancreatic carcinoma locus 4(DPC4) inactivation. The two models were established simultaneously using the tumor of a single patient. Tumor formation was observed for at least 6 months after tumor implantation. The established tumors persisted for at least three passages through re-transplantation in other NSG mice. In total, 17 cases of PDOX (68.0\%) and 18 cases of PDHX (72.0\%) were established, indicating a similar high success rate of each model (Table 1). Thirteen cases $(52.0 \%)$ were established in both models, and four cases $(16.0 \%)$ were not established in either model (Supplementary Table 1).

No significant differences $(p>0.05)$ were found in the clinical data of patients with tumors that were successfully established in both models $(n=13)$ compared to the others $(n=12)$ (Table 1). Four of the 13 PDXs established in both models (Nos. 1, 7, 16, and 25) were selected for comparison of homology and heterogeneity between the PDOX/PDHX tumors and the original patient tumor (Supplementary Table 1).

\section{Histological comparison of the original patient tumors and PDOX and PDHX models}

Hematoxylin and eosin (H\&E) staining was carried out. The pancreatic ducts identified in the H\&E staining of the original patient tumor were similar in the corresponding PDOX and PDHX groups (Figure 1).

\section{Immunohistochemical analysis of gene expression}

Immunohistochemistry analysis was performed using anti-P53, -c-erbB-2, and -DPC4 antibodies (Figure 1). As shown in Supplementary Table 1, the degree of expression in each primary carcinoma was quantified, and these findings were confirmed by experienced pancreatic cancer pathologists. A similar degree of expression of p53, c-erbB-2, and DPC4 was detected in the PDOX and PDHX models and the original patient tumor.

\section{SNP comparison among the original patient tumors and the PDOX and PDHX models}

The single nucleotide polymorphism (SNP) profiles of PDOX and PDHX pairs were compared to each other as well as to their original patient tumors. At least $96.8 \%$ of the SNPs were found to be identical between the PDOX and PDHX groups (Figure 2A). The SNP patterns among the three groups (original patient cancer, PDOX, and PDHX) showed a similarity rate ranging between $88.2 \%$ and $92.7 \%$, with an average of $89.9 \%$ of the SNPs of the original patient 
tumor maintained in both models (Figure 2B). Phylogenetic analysis demonstrated four groups of clusters, corresponding to the respective patient groups (Figure 2C). Informationbased similarity-matrix analysis also showed a clear linear correlation, indicating that both xenograft models were most strongly correlated to their respective original tumors.

The original patient tumor and the two PDXs were further analyzed as pairs. For all the SNP sites, the two

A

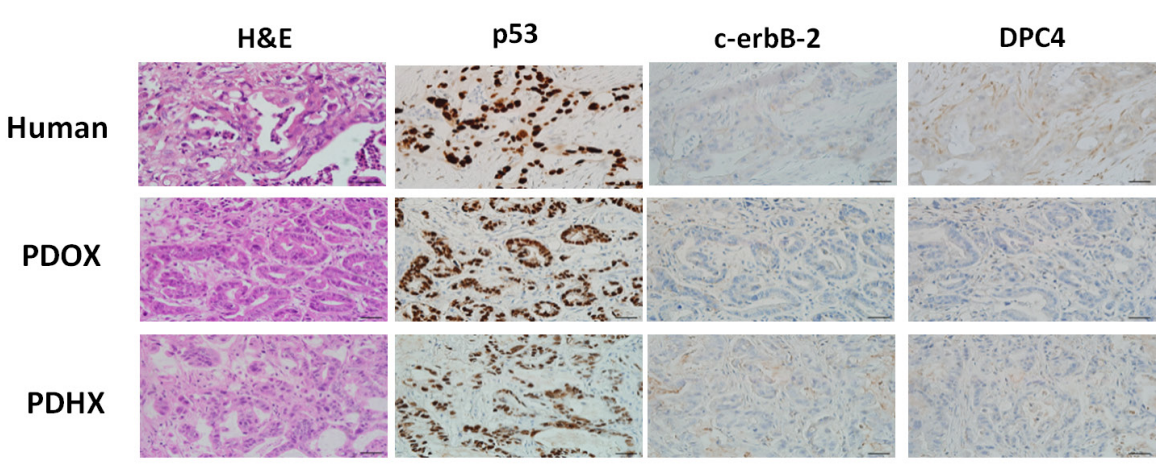

B

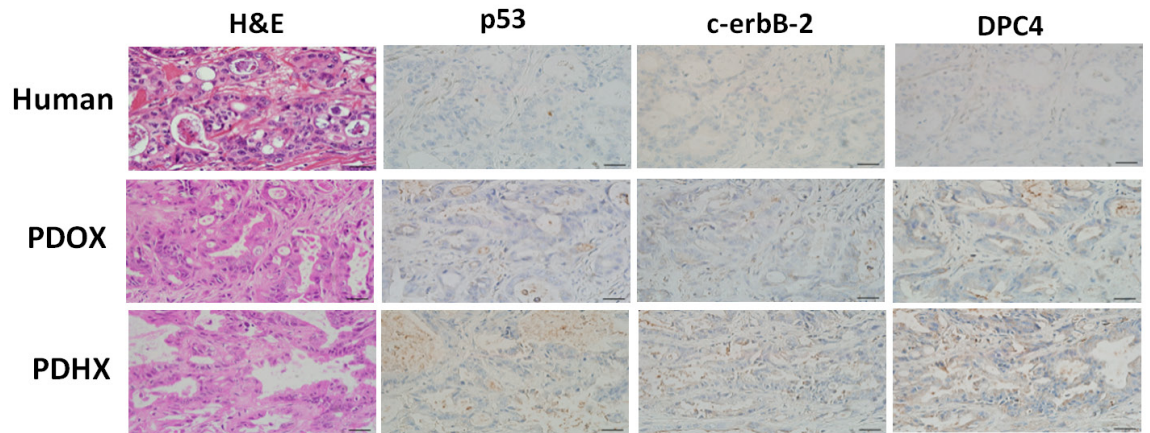

C
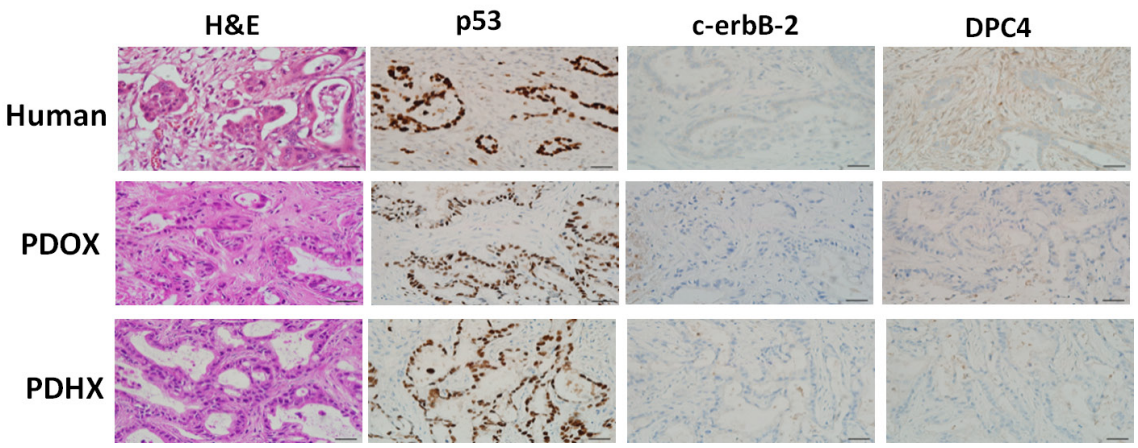

D

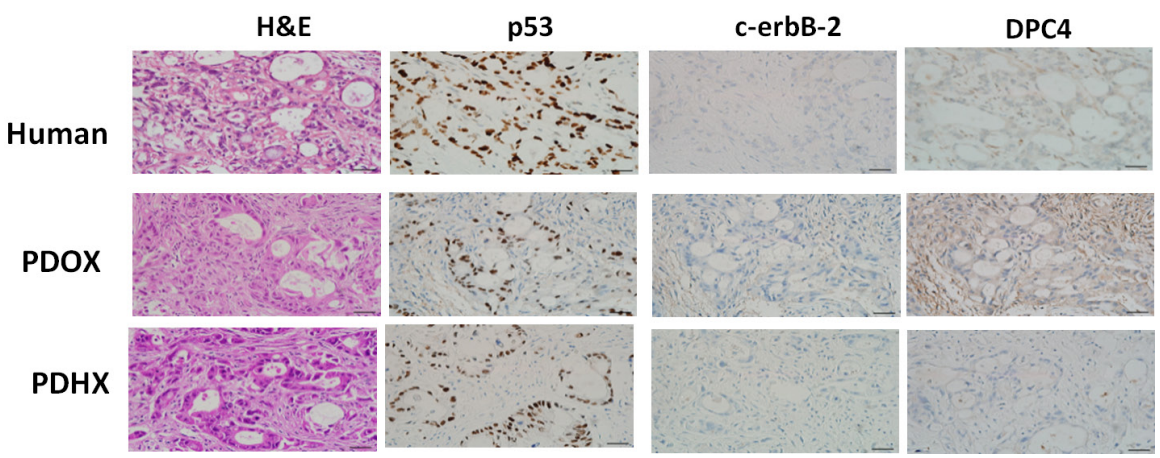

Figure 1: Immunohistochemistry analysis of the original patient tumors compared with patient-derived xenografts PDOX and PDHX. Images of H\&E, p53, C-erbB-2, and DPC4 staining of patient-PDXs pairs. A-D refer to patient sets No. 1, 7, 16, and 25, respectively. (Size bar : $20 \mu \mathrm{m}$ ). 
Table 1: Host and tumor characteristics for PDX establishment in pancreatic cancer

\begin{tabular}{|c|c|c|c|c|c|c|c|}
\hline \multirow{2}{*}{ Characteristics } & \multirow{2}{*}{$\begin{array}{c}\text { All } \\
(n=25,100 \%)\end{array}$} & \multicolumn{3}{|c|}{ PDX generation $(n, \%)$} & \multicolumn{3}{|c|}{ PDOX \& PDHX generation $(n, \%)$} \\
\hline & & $\begin{array}{c}\text { PDOX } \\
(n=17,68.0 \%)\end{array}$ & $\begin{array}{c}\text { PDHX } \\
(n=18,72.0 \%)\end{array}$ & $\begin{array}{c}P \\
\text { value }\end{array}$ & $\begin{array}{c}\text { both } \\
(n=13,52.0 \%)\end{array}$ & $\begin{array}{c}\text { none } \\
(n=12,48.0 \%)\end{array}$ & $\begin{array}{c}P \\
\text { value }\end{array}$ \\
\hline \multicolumn{8}{|l|}{ Age, y } \\
\hline mean (SD) & $61.8 \pm 8.2$ & $60.23 \pm 8.51$ & $62.17 \pm 7.69$ & 0.486 & $60.8 \pm 8.07$ & $63.1 \pm 8.73$ & 0.498 \\
\hline \multicolumn{8}{|l|}{ Gender, $n(\%)$} \\
\hline Female & $14(56 \%)$ & $11(31.4 \%)$ & $12(34.3 \%)$ & & $9(36.0 \%)$ & $5(20.0 \%)$ & \\
\hline Male & $11(44 \%)$ & $6(17.1 \%)$ & $6(17.1 \%)$ & 0.903 & $4(16.0 \%)$ & $7(28.0 \%)$ & 0.238 \\
\hline \multicolumn{8}{|l|}{ Type of operation, $n(\%)$} \\
\hline PD & $19(76 \%)$ & $12(34.3 \%)$ & $13(37.1 \%)$ & & $8(32.0 \%)$ & $11(44.0 \%)$ & \\
\hline DP & $6(24 \%)$ & $5(14.3 \%)$ & $5(14.3 \%)$ & 0.915 & $5(20.0 \%)$ & $1(4.0 \%)$ & 0.160 \\
\hline \multicolumn{8}{|l|}{ Tumor size $(\mathrm{cm})$} \\
\hline mean (SD) & $3.35 \pm 0.9$ & $3.48 \pm 1.01$ & $3.40 \pm 1.02$ & 0.825 & $3.5 \pm 1.10$ & $3.3 \pm 0.68$ & 0.589 \\
\hline \multicolumn{8}{|c|}{ Tumor differentiation, $n(\%)$} \\
\hline WD & $1(4 \%)$ & $1(2.9 \%)$ & $1(2.9 \%)$ & & $1(4.0 \%)$ & $0(0 \%)$ & \\
\hline MD & $22(88 \%)$ & $14(40.0 \%)$ & $15(42.9 \%)$ & & $4(40.0 \%)$ & $12(48.0 \%)$ & \\
\hline PD & $2(8 \%)$ & $2(5.7 \%)$ & $2(5.7 \%)$ & 0.997 & $2(8.0 \%)$ & $0(0 \%)$ & 0.207 \\
\hline \multicolumn{8}{|l|}{ T stage, $n(\%)$} \\
\hline $\mathrm{T} 3$ & $25(100 \%)$ & $17(48.6 \%)$ & $18(51.4 \%)$ & & $13(52.0 \%)$ & $12(48.0 \%)$ & \\
\hline \multicolumn{8}{|l|}{ N stage, $n(\%)$} \\
\hline No & $5(20 \%)$ & $4(11.4 \%)$ & $5(14.3 \%)$ & & $3(12.0 \%)$ & $2(8.0 \%)$ & \\
\hline N1 & $20(80 \%)$ & $13(37.1 \%)$ & $13(37.1 \%)$ & 0.774 & $10(40.0 \%)$ & $10(40.0 \%)$ & 0.689 \\
\hline \multicolumn{8}{|l|}{ M stage, $n(\%)$} \\
\hline M0 & $23(92 \%)$ & $15(42.9 \%)$ & $16(45.7 \%)$ & & $11(44.0 \%)$ & $12(48.0 \%)$ & \\
\hline M1* & $2(8 \%)$ & $2(5.7 \%)$ & $2(5.7 \%)$ & 0.952 & $2(8.0 \%)$ & $0(0 \%)$ & 0.157 \\
\hline \multicolumn{8}{|l|}{$\mathrm{p} 53, n(\%)$} \\
\hline normal & $7(28 \%)$ & $5(14.3 \%)$ & $4(11.4 \%)$ & & $3(12.0 \%)$ & $4(16.0)$ & \\
\hline inactivated & $18(72 \%)$ & $12(34.3 \%)$ & $14(40.0 \%)$ & 0.627 & $10(40.0 \%)$ & $8(32.0 \%)$ & 0.568 \\
\hline \multicolumn{8}{|l|}{ C-erbB-2, $n(\%)$} \\
\hline normal & $18(72 \%)$ & $14(40.0 \%)$ & $14(40.0 \%)$ & & $10(40.0 \%)$ & $8(32.0 \%)$ & \\
\hline overexpressed & $7(28 \%)$ & $3(8.6 \%)$ & $4(11.4 \%)$ & 0.735 & $3(12.0 \%)$ & $4(16.0 \%)$ & 0.568 \\
\hline \multicolumn{8}{|l|}{ DPC $4, n(\%)$} \\
\hline normal & $14(56 \%)$ & $11(31.4 \%)$ & $9(25.7 \%)$ & & $7(28.0 \%)$ & $7(28.0 \%)$ & \\
\hline inactivated & $11(44 \%)$ & $6(17.1 \%)$ & $9(25.7 \%)$ & 0.380 & $6(24.0 \%)$ & $5(20.0 \%)$ & 0.821 \\
\hline
\end{tabular}

PD, pancreatico-duodenectomy; DP, distal pancreatectomy; WD, well differentiated; MD, moderately differentiated; PD, poorly differentiated; DPC4, deleted in pancreatic carcinoma locus $4 .{ }^{*}$ All of the metastases were liver.

xenograft models showed an average $92.1 \%$ homology to their primary tumors (Figure 2E). For SNP sites of tumorspecific genes, $90.5 \%$ of PDOX and $91.5 \%$ of PDHX showed the same polymorphisms as the original patient cancer [36] (Figure 2). There was no significant difference from the original patient tumor in either of the two models $(P>0.05)$. To further clarify the differences between each model in cancer-specific gene SNPs, additional analyses were performed for only the 3562 SNP sites that were commonly identified in the analysis of the original patient tumor and PDOX and PDHX models of the four groups (patients no. 1, 7, 16, and 25). The homology of SNPs at these sites was as follows (PDOX vs. PDHX): patient no. $1,99.9 \%$ vs. $97.8 \%$; patient no. $7,96.9 \%$ vs. $97.4 \%$; patient no. $16,96.0 \%$ vs. $95.9 \%$; and patient no. $25,94.4 \%$ vs. $94.3 \%$ (Table 2, Figure $2 \mathrm{G}$ ). As shown in Table 2, the degree of similarity was similar for all genes tested. Six genes [BRCA2, NBEA (patient no. 7), HIVEP1, SMAD3, $S D K 2$, and $S P T B$ (patient no. 16)] with the highest levels of SNPs were then selected for further analysis of SNP patterns. Although the SNP patterns differed from those of the original patient tumor to some extent in the PDX models, they were completely identical between the PDOX and PDHX groups (Supplementary Tables 2 and 


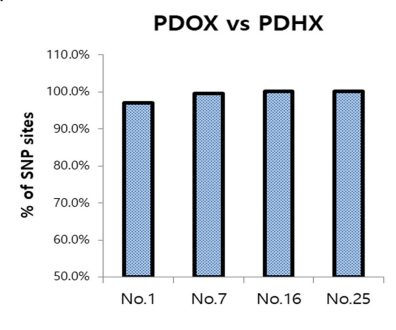

C
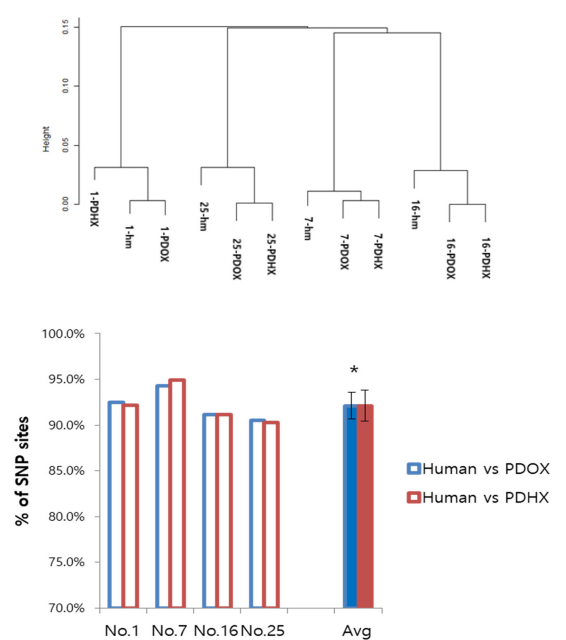

G

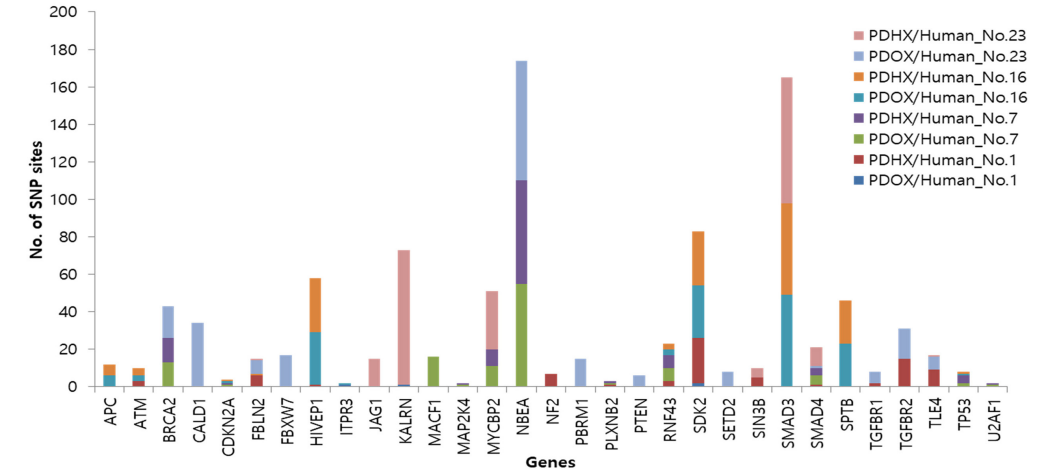

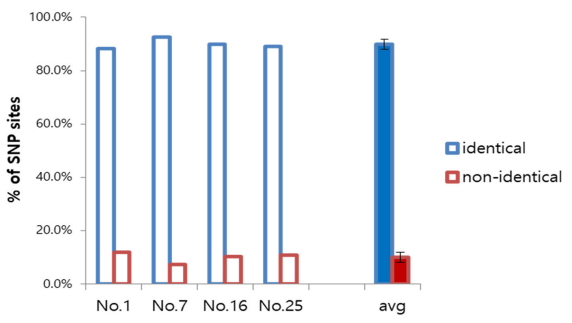

D

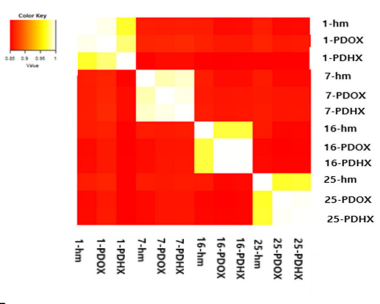

$\mathrm{F}$

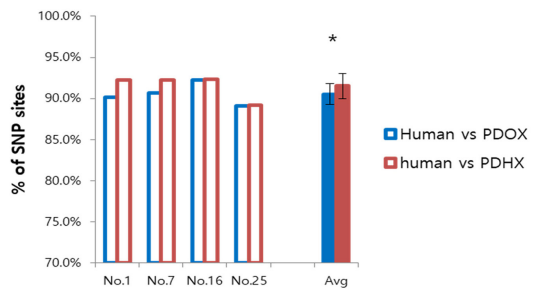

$\mathrm{H}$
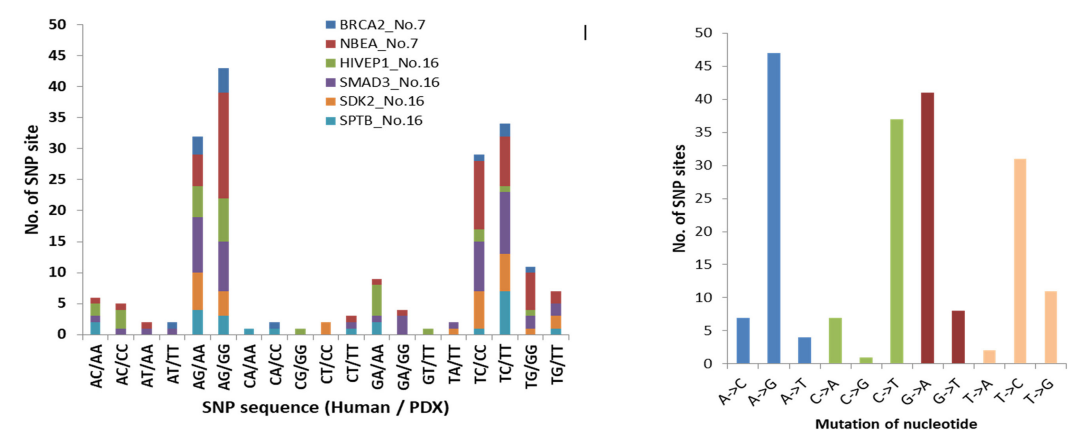

Figure 2: Comparative analysis of single-nucleotide polymorphism (SNP) arrays between the original patient tumor and PDOX and PDHX. (A) Homology between PDOX and PDHX for cancer-specific SNP sites. At least $96.8 \%$ of the SNPs were identical. (B) SNPs in original patient tumors were compared to those in both the PDOX and PDHX models. There was a slight difference in each group, but the average identification rate was $89.9 \%$. (C) Phylogenetic tree showing group clustering according to the patient tumor. (D) Information-based similarity (IBS) matrix based on the SNP variants among human tumors and PDXs. (E) Homology between human tumors and PDXs for all SNP sites. There was no significant difference between the groups $\left({ }^{*} p=0.985\right)$. (F) Homology between human tumors and PDXs for cancer-specific SNP sites. There was no significant difference between the groups ( $\left.{ }^{*} p=0.379\right)$. (G) Comparative analysis of SNP sites of cancer-specific genes. (H) Comparison of nucleotide sequences in six representative cases showing a high SNP difference. (I) Pattern of nucleotide-sequence changes. 
Table 2: Comparative analysis of the SNP mutations in cancer-related genes of patient-derived xenografts

\begin{tabular}{|c|c|c|c|c|c|c|c|c|c|c|c|c|c|c|c|c|}
\hline \multirow{3}{*}{$\begin{array}{l}\text { Gene(s) / No. of } \\
\text { SNP sites }\end{array}$} & \multicolumn{4}{|c|}{ Group No.1 } & \multicolumn{4}{|c|}{ Group No.7 } & \multicolumn{4}{|c|}{ Group No.16 } & \multicolumn{4}{|c|}{ Group No.23 } \\
\hline & \multicolumn{2}{|c|}{$\begin{array}{l}\text { PDOX } \\
\text { /human }\end{array}$} & \multicolumn{2}{|c|}{$\begin{array}{c}\text { PDHX } \\
\text { /human }\end{array}$} & \multicolumn{2}{|c|}{$\begin{array}{l}\text { PDOX } \\
\text { /human }\end{array}$} & \multicolumn{2}{|c|}{$\begin{array}{c}\text { PDHX } \\
\text { /human }\end{array}$} & \multicolumn{2}{|c|}{$\begin{array}{c}\text { PDOX } \\
\text { /human }\end{array}$} & \multicolumn{2}{|c|}{$\begin{array}{c}\text { PDHX } \\
\text { /human }\end{array}$} & \multicolumn{2}{|c|}{$\begin{array}{c}\text { PDOX } \\
\text { /human }\end{array}$} & \multicolumn{2}{|c|}{$\begin{array}{c}\text { PDHX } \\
\text { /human }\end{array}$} \\
\hline & o & $\mathbf{x}$ & o & $\mathbf{x}$ & o & $\mathbf{X}$ & o & $\mathbf{x}$ & o & $\mathbf{x}$ & o & $\mathbf{X}$ & $\mathbf{O}$ & $\mathbf{x}$ & o & $\mathbf{X}$ \\
\hline ACVR2A/39 & 39 & 0 & 39 & 0 & 39 & 0 & 39 & 0 & 39 & 0 & 39 & 0 & 39 & 0 & 39 & 0 \\
\hline $\begin{array}{l}\mathrm{APC} \\
/ 73\end{array}$ & 73 & 0 & 73 & 0 & 73 & 0 & 73 & 0 & 67 & 6 & 67 & 6 & 73 & 0 & 73 & 0 \\
\hline $\begin{array}{l}\text { ARID1A } \\
/ 32\end{array}$ & 32 & 0 & 32 & 0 & 32 & 0 & 32 & 0 & 32 & 0 & 32 & 0 & 32 & 0 & 32 & 0 \\
\hline $\begin{array}{l}\text { ATM } \\
/ 76\end{array}$ & 76 & 0 & 73 & 3 & 76 & 0 & 76 & 0 & 73 & 3 & 72 & 4 & 76 & 0 & 76 & 0 \\
\hline $\begin{array}{l}\text { BCORL1 } \\
/ 10\end{array}$ & 10 & 0 & 10 & 0 & 10 & 0 & 10 & 0 & 10 & 0 & 10 & 0 & 10 & 0 & 10 & 0 \\
\hline $\begin{array}{l}\text { BRCA1 } \\
135\end{array}$ & 35 & 0 & 35 & 0 & 35 & 0 & 35 & 0 & 35 & 0 & 35 & 0 & 35 & 0 & 35 & 0 \\
\hline $\begin{array}{l}\text { BRCA2 } \\
/ 71\end{array}$ & 71 & 0 & 71 & 0 & 58 & 13 & 58 & 13 & 71 & 0 & 71 & 0 & 54 & 17 & 71 & 0 \\
\hline $\begin{array}{l}\text { CALD1 } \\
/ 166\end{array}$ & 166 & 0 & 166 & 0 & 166 & 0 & 166 & 0 & 166 & 0 & 166 & 0 & 132 & 34 & 166 & 0 \\
\hline $\begin{array}{l}\text { DISP2 } \\
/ 6\end{array}$ & 6 & 0 & 6 & 0 & 6 & 0 & 6 & 0 & 5 & 1 & 5 & 1 & 6 & 0 & 6 & 0 \\
\hline $\begin{array}{l}\text { FBLN2 } \\
/ 73\end{array}$ & 73 & 0 & 67 & 6 & 73 & 0 & 73 & 0 & 73 & 0 & 72 & 1 & 66 & 7 & 72 & 1 \\
\hline $\begin{array}{l}\text { FBXW7 } \\
/ 87\end{array}$ & 87 & 0 & 87 & 0 & 87 & 0 & 87 & 0 & 87 & 0 & 87 & 0 & 70 & 17 & 87 & 0 \\
\hline $\begin{array}{l}\text { HIVEP1 } \\
/ 139\end{array}$ & 139 & 0 & 138 & 1 & 139 & 0 & 139 & 0 & 111 & 28 & 110 & 29 & 139 & 0 & 139 & 0 \\
\hline $\begin{array}{l}\text { ITPR3 } \\
\text { /91 }\end{array}$ & 90 & 1 & 91 & 0 & 91 & 0 & 91 & 0 & 90 & 1 & 91 & 0 & 91 & 0 & 91 & 0 \\
\hline $\begin{array}{l}\text { JAG1 } \\
/ 49\end{array}$ & 49 & 0 & 49 & 0 & 49 & 0 & 49 & 0 & 49 & 0 & 49 & 0 & 49 & 0 & 34 & 15 \\
\hline $\begin{array}{l}\text { KALRN } \\
/ 539\end{array}$ & 538 & 1 & 539 & 0 & 539 & 0 & 539 & 0 & 539 & 0 & 539 & 0 & 539 & 0 & 467 & 72 \\
\hline $\begin{array}{l}\text { KDM6A } \\
/ 84\end{array}$ & 84 & 0 & 84 & 0 & 84 & 0 & 84 & 0 & 84 & 0 & 84 & 0 & 84 & 0 & 84 & 0 \\
\hline $\begin{array}{l}\text { KRAS } \\
/ 46\end{array}$ & 46 & 0 & 46 & 0 & 46 & 0 & 46 & 0 & 46 & 0 & 46 & 0 & 46 & 0 & 46 & 0 \\
\hline $\begin{array}{l}\text { MACF1 } \\
/ 187\end{array}$ & 187 & 0 & 187 & 0 & 171 & 16 & 187 & 0 & 187 & 0 & 187 & 0 & 187 & 0 & 187 & 0 \\
\hline $\begin{array}{l}\text { MAP2K4 } \\
/ 3\end{array}$ & 3 & 0 & 3 & 0 & 2 & 1 & 2 & 1 & 3 & 0 & 3 & 0 & 3 & 0 & 3 & 0 \\
\hline $\begin{array}{l}\text { MLL3 } \\
/ 122\end{array}$ & 122 & 0 & 122 & 0 & 122 & 0 & 122 & 0 & 122 & 0 & 122 & 0 & 122 & 0 & 122 & 0 \\
\hline $\begin{array}{l}\text { MYCBP2 } \\
/ 115\end{array}$ & 115 & 0 & 115 & 0 & 104 & 11 & 106 & 9 & 115 & 0 & 115 & 0 & 115 & 0 & 84 & 31 \\
\hline $\begin{array}{l}\text { NBEA } \\
/ 391\end{array}$ & 391 & 0 & 391 & 0 & 336 & 55 & 336 & 55 & 391 & 0 & 391 & 0 & 327 & 64 & 391 & 0 \\
\hline $\begin{array}{l}\text { NF2 } \\
/ 43\end{array}$ & 43 & 0 & 36 & 7 & 43 & 0 & 43 & 0 & 43 & 0 & 43 & 0 & 43 & 0 & 43 & 0 \\
\hline $\begin{array}{l}\text { PBRM1 } \\
/ 50\end{array}$ & 50 & 0 & 50 & 0 & 50 & 0 & 50 & 0 & 50 & 0 & 50 & 0 & 35 & 15 & 50 & 0 \\
\hline $\begin{array}{l}\text { PLXNB2 } \\
/ 10\end{array}$ & 10 & 0 & 9 & 1 & 9 & 1 & 9 & 1 & 10 & 0 & 10 & 0 & 10 & 0 & 10 & 0 \\
\hline $\begin{array}{l}\text { PTEN } \\
/ 48\end{array}$ & 48 & 0 & 48 & 0 & 48 & 0 & 48 & 0 & 48 & 0 & 48 & 0 & 42 & 6 & 48 & 0 \\
\hline $\begin{array}{l}\text { RBM10 } \\
/ 10\end{array}$ & 10 & 0 & 10 & 0 & 10 & 0 & 10 & 0 & 10 & 0 & 10 & 0 & 10 & 0 & 10 & 0 \\
\hline $\begin{array}{l}\text { RNF43 } \\
\text { /43 }\end{array}$ & 43 & 0 & 40 & 3 & 36 & 7 & 36 & 7 & 40 & 3 & 40 & 3 & 43 & 0 & 43 & 0 \\
\hline $\begin{array}{l}\text { SDK2 } \\
/ 242\end{array}$ & 240 & 2 & 218 & 24 & 242 & 0 & 242 & 0 & 214 & 28 & 213 & 29 & 242 & 0 & 242 & 0 \\
\hline $\begin{array}{l}\text { SETD2 } \\
150\end{array}$ & 50 & 0 & 50 & 0 & 50 & 0 & 50 & 0 & 50 & 0 & 50 & 0 & 42 & 8 & 50 & 0 \\
\hline $\begin{array}{l}\text { SF3B1 } \\
/ 13\end{array}$ & 13 & 0 & 13 & 0 & 13 & 0 & 13 & 0 & 13 & 0 & 13 & 0 & 13 & 0 & 13 & 0 \\
\hline
\end{tabular}


Table 2: Continued

\begin{tabular}{|c|c|c|c|c|c|c|c|c|c|c|c|c|c|c|c|c|}
\hline $\begin{array}{l}\text { SIN3B } \\
/ 20\end{array}$ & 20 & 0 & 15 & 5 & 20 & 0 & 20 & 0 & 20 & 0 & 20 & 0 & 20 & 0 & 15 & 5 \\
\hline $\begin{array}{l}\text { SMAD3 } \\
/ 158\end{array}$ & 158 & 0 & 158 & 0 & 158 & 0 & 158 & 0 & 109 & 49 & 109 & 49 & 158 & 0 & 91 & 67 \\
\hline $\begin{array}{l}\text { SMAD4 } \\
/ 24\end{array}$ & 24 & 0 & 23 & 1 & 19 & 5 & 20 & 4 & 24 & 0 & 24 & 0 & 23 & 1 & 14 & 10 \\
\hline SMARCA4/38 & 38 & 0 & 38 & 0 & 38 & 0 & 38 & 0 & 38 & 0 & 38 & 0 & 38 & 0 & 38 & 0 \\
\hline $\begin{array}{l}\text { SPTB } \\
/ 99\end{array}$ & 99 & 0 & 99 & 0 & 99 & 0 & 99 & 0 & 76 & 23 & 76 & 23 & 99 & 0 & 99 & 0 \\
\hline $\begin{array}{l}\text { TGFBR1 } \\
/ 27\end{array}$ & 27 & 0 & 25 & 2 & 27 & 0 & 27 & 0 & 27 & 0 & 27 & 0 & 21 & 6 & 27 & 0 \\
\hline $\begin{array}{l}\text { TGFBR2 } \\
/ 101\end{array}$ & 101 & 0 & 86 & 15 & 101 & 0 & 101 & 0 & 101 & 0 & 101 & 0 & 85 & 16 & 101 & 0 \\
\hline $\begin{array}{l}\text { TLE4 } \\
/ 92\end{array}$ & 92 & 0 & 83 & 9 & 92 & 0 & 92 & 0 & 92 & 0 & 92 & 0 & 85 & 7 & 91 & 1 \\
\hline $\begin{array}{l}\text { TP53 } \\
/ 45\end{array}$ & 45 & 0 & 45 & 0 & 43 & 2 & 41 & 4 & 44 & 1 & 44 & 1 & 45 & 0 & 45 & 0 \\
\hline $\begin{array}{l}\text { U2AF1 } \\
/ 15\end{array}$ & 15 & 0 & 15 & 0 & 15 & 0 & 15 & 0 & 15 & 0 & 15 & 0 & 15 & 0 & 15 & 0 \\
\hline $\begin{array}{l}\text { Total (\%) } \\
N=3562\end{array}$ & $\begin{array}{c}3558 \\
(99.9 \%)\end{array}$ & $\begin{array}{c}4 \\
(0.1 \%)\end{array}$ & $\begin{array}{c}3485 \\
(97.8 \%)\end{array}$ & $\begin{array}{c}77 \\
(2.2 \%)\end{array}$ & $\begin{array}{c}3451 \\
(96.9 \%)\end{array}$ & $\begin{array}{c}111 \\
(3.1 \%)\end{array}$ & $\begin{array}{c}3468 \\
(97.4 \%)\end{array}$ & $\begin{array}{c}94 \\
(2.6 \%)\end{array}$ & $\begin{array}{c}3419 \\
(96.0 \%)\end{array}$ & $\begin{array}{c}143 \\
(4.0 \%)\end{array}$ & $\begin{array}{c}3416 \\
(95.9 \%)\end{array}$ & $\begin{array}{c}146 \\
(4.1 \%)\end{array}$ & $\begin{array}{c}3364 \\
(94.4 \%)\end{array}$ & $\begin{array}{c}198 \\
(5.6 \%)\end{array}$ & $\begin{array}{c}3360 \\
(94.3 \%)\end{array}$ & $\begin{array}{c}202 \\
(5.7 \%)\end{array}$ \\
\hline
\end{tabular}

3). The most frequently observed mutations were $A>G$, $\mathrm{C}>\mathrm{T}, \mathrm{G}>\mathrm{A}$, and $\mathrm{T}>\mathrm{C}$ (Figure $2 \mathrm{H}, 2 \mathrm{I}$ ).

\section{DNA methylation analysis comparing the original patient tumors and the PDOX and PDHX models}

Genome-wide DNA methylation patterns were analyzed according to methylation intensity among the original patient tumors and PDOX, and PDHX models. For each patient, the 2 PDX models and original-patient tumors showed similar patterns with respect to the number of methylated $\mathrm{CpG}$ sites (Figure $3 \mathrm{~A}$ ). In addition, $1000 \mathrm{CpG}$ sites were randomly selected for statistical comparison of methylation homology. As shown in Figure $3 \mathrm{~B}$, the original patient tumors showed $89.75 \%$ and $88.5 \%$ mean similarity to PDOX and PDHX, respectively, among the four cases. PDOX and PDHX showed 95.5\% homology. Furthermore, we compared the degrees of hypermethylation and hypomethylation according to genomic compartments in the PDOX and PDHX models relative to the original patient tumors. Although similarity was observed in the methylation patterns of the selected genomic compartments, the PDHX model showed a slight increase in the degree of both hypermethylated and hypomethylated sites (Figure 3C). This difference was evident when analyzing the global hypermethylation and hypomethylation patterns between the PDOX and PDHX models and the original patient tumors; however, there was no statistical significance between the two xenograft models (Figure 3D). Additional analysis of the 1425 methylation sites of cancer-specific genes was performed. As shown in Table 3, a similar number of DNA methylation sites was maintained in the PDOX and PDHX models for each patient (1370 vs. 1265 , respectively, in patient no. 1; 1299 vs. 1302, respectively, in patient no.
$7 ; 1321$ vs. 1300 , respectively, in patient no. 16 ; and 1290 vs. 1291 , respectively, in patient no. 25). The average degree of methylation (hyper/hypo) in the four groups was $2.3 \% / 3.6 \%$ in the PDOX models and $1.1 \% / 5.5 \%$ in the PDHX models (Supplementary Table 4).

Regarding individual gene analysis, the PDOX group had more hypermethylation, whereas the PDHX group had more hypomethylation (Figure 3E-3G). Of the sites with altered methylation patterns, $36.5-87.5 \%$ overlapped, and the methylation changes of these overlapping sites were similar in the PDOX and PDHX models (Figure $3 \mathrm{H}$ ). However, patient no. 25 showed a slightly different pattern from the other groups, similar to the SNP analysis.

\section{Metabolite analysis comparing the original patient tumors and PDOX and PDHX models}

Quantitative comparison of various metabolites was also performed as shown in Figure 4A. Heatmap analysis showed that the original patient tumor tended to have higher amounts of glycolysis metabolites and lower amounts of metabolites related to the tricarboxylic acid (TCA) cycle and pentose-phosphate pathway compared to normal tissues (Figure 4B). When glycolysis metabolites were low in cancer tissues such as the original patient tumor \#1 and PDOX and PDHX from this patient, the metabolites of the TCA and pentose-phosphate pathway were also low. By contrast, metabolites related to the TCA cycle and pentose-phosphate pathway were always more highly activated than those related to glycolysis in normal tissues. Accordingly, the tumors that developed in the PDOX and PDX mice generally showed activated glycolysis, known as the Warburg effect. Thirteen of the total 23 metabolites were not significantly different from those of the original primary tumor for both PDOX and 
PDAX models, and five metabolites differed in both groups (Figure 4C). Specifically, 3-phosphoglyceric acid (3PG) showed a difference from the original patient tumor only in the PDOX model, and metabolites such as fructose 1,6-bisphosphatase (FBP), alpha-ketoglutaric acid (AKG), were found to differ from the original patient tumor only in the PDHX models.

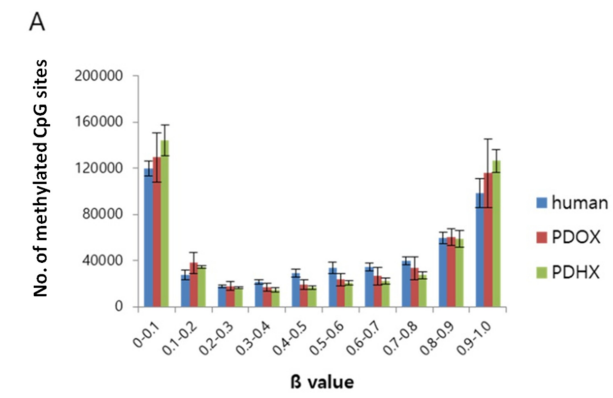

C
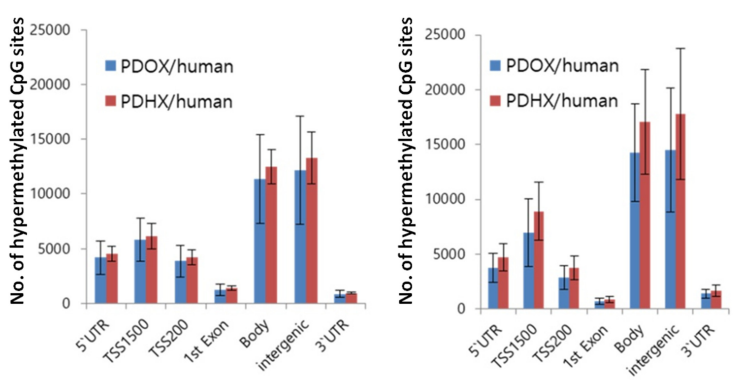

\section{DISCUSSION}

For the simultaneous establishment of PDOX and PDHX models with the same patient tumor, only patients with a relatively large tumor size (average size $3.35 \mathrm{~cm}$ ) were included in the present study since we previously showed tumors of this size had high PDX-establishment

B

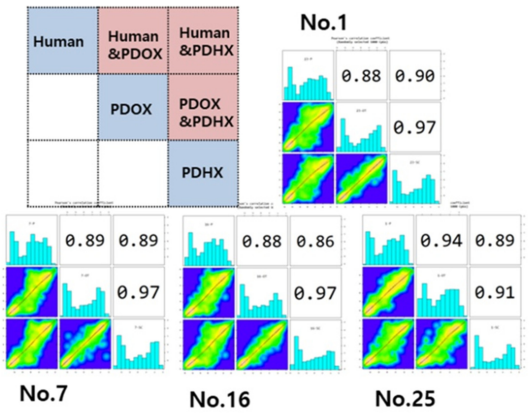

D

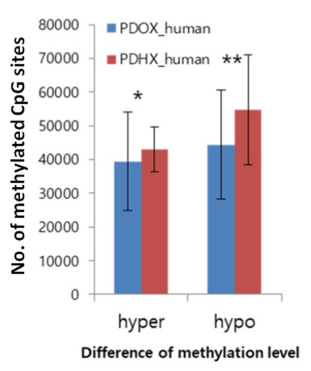

E. Methylation-unchanged

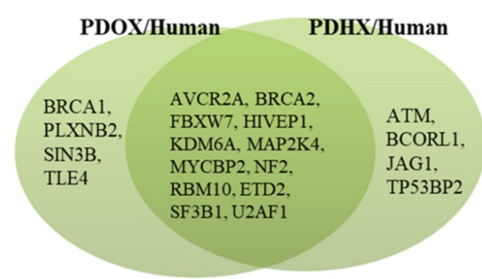

G. Changed-hypomethylation

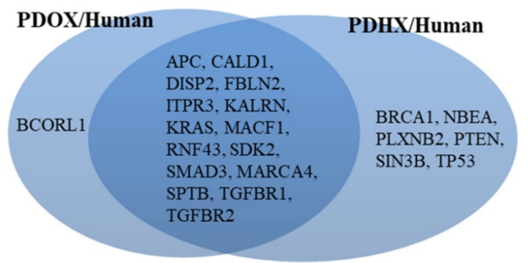

F. Changed-hypermethylation

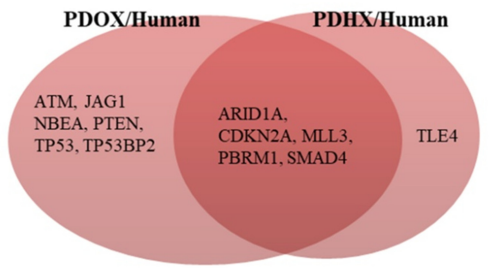

H.

\begin{tabular}{|c|c|c|c|c|c|}
\hline \multirow{2}{*}{ No. of Group } & \multirow{2}{*}{\begin{tabular}{|c|} 
No. of methylation site \\
overllaped site / changed site (\%)
\end{tabular}} & \multicolumn{4}{|c|}{$\begin{array}{l}\text { Methylation status of overllapped site } \\
\text { PDOX/human }>\text { PDHX/human }\end{array}$} \\
\hline & & hyper->hyper & hypo->hypo & hyper->hypo & hypo $>>$ hyper \\
\hline$\# 1$ & $20 / 55(36.4 \%)$ & 2 & 18 & 0 & 0 \\
\hline$\$ 7$ & $98 / 126(77.8 \%)$ & 12 & 86 & 0 & 0 \\
\hline$\# 16$ & $91 / 104(87.5 \%)$ & 12 & 79 & 0 & 0 \\
\hline$\# 25$ & $105 / 135(77.8 \%)$ & 36 & 7 & 55 & 7 \\
\hline
\end{tabular}

Figure 3: Comparative analysis of DNA methylation arrays between original patient tumors and PDOX and PDHX. (A) Distribution of methylation levels by group; $\beta$ values are grouped in 0.1 increments and the percentage of probes is represented for each sample type. (B) Pearson's correlation analysis. Of the total methylation sites, 1000 sites were randomly selected. As shown in the box at the top left, the methylation patterns of the original patient tumors, PDOX, and PDHX were compared. The analysis was performed for four human-PDOX and PDHX sets. (C) Methylation intensity by genomic compartment. The delta value was calculated by analyzing the methylation-intensity difference between the comparison subjects; hypermethylation was defined as delta $\geq 0.2$ and hypomethylation was defined as delta $\leq-0.2$. Each methylation level was compared according to the genomic compartment. (D) Methylation intensity between two groups. Genomic compartments were not distinguished, and the overall intensity was analyzed together $\left({ }^{*} p=0.678 ;{ }^{* *} p=0.401\right)$. (E-G) Comparison of methylation changes for cancer-specific genes: (E) unchanged, (F) hypermethylation, (G) hypomethylation. (H) Comparison of methylation patterns for methylation-changed sites. 
Table 3: Comparative analysis of DNA methylation in cancer-related genes of patient-derived xenografts

\begin{tabular}{|c|c|c|c|c|c|c|c|c|c|c|c|c|c|c|c|c|}
\hline \multirow{3}{*}{$\begin{array}{l}\text { Gene } \\
\text { /No. of } \\
\text { methylation } \\
\text { site }\end{array}$} & \multicolumn{4}{|c|}{ Group No.1 } & \multicolumn{4}{|c|}{ Group No.7 } & \multicolumn{4}{|c|}{ Group No.16 } & \multicolumn{4}{|c|}{ Group No.23 } \\
\hline & \multicolumn{2}{|c|}{$\begin{array}{l}\text { PDOX/ } \\
\text { human }\end{array}$} & \multicolumn{2}{|c|}{$\begin{array}{l}\text { PDHX/ } \\
\text { human }\end{array}$} & \multicolumn{2}{|c|}{$\begin{array}{l}\text { PDOX/ } \\
\text { human }\end{array}$} & \multicolumn{2}{|c|}{$\begin{array}{l}\text { PDHX/ } \\
\text { human }\end{array}$} & \multicolumn{2}{|c|}{$\begin{array}{l}\text { PDOX/ } \\
\text { human }\end{array}$} & \multicolumn{2}{|c|}{$\begin{array}{l}\text { PDHX/ } \\
\text { human }\end{array}$} & \multicolumn{2}{|c|}{$\begin{array}{l}\text { PDOX/ } \\
\text { human }\end{array}$} & \multicolumn{2}{|c|}{$\begin{array}{l}\text { PDHX/ } \\
\text { human }\end{array}$} \\
\hline & $\mathbf{X}$ & $\begin{array}{c}\mathbf{O} \\
+/-\end{array}$ & $\mathbf{X}$ & $\begin{array}{c}\mathbf{O} \\
+/-\end{array}$ & $\mathbf{X}$ & $\begin{array}{c}\mathbf{O} \\
+/-\end{array}$ & $\mathbf{X}$ & $\begin{array}{c}\mathbf{O} \\
+/-\end{array}$ & $\mathbf{X}$ & $\begin{array}{c}\mathbf{O} \\
+/-\end{array}$ & $\mathbf{X}$ & $\begin{array}{c}\mathbf{O} \\
+/-\end{array}$ & $\mathbf{X}$ & $\begin{array}{c}\mathbf{O} \\
+/-\end{array}$ & $\mathbf{X}$ & $\begin{array}{c}\mathbf{O} \\
+/-\end{array}$ \\
\hline ACVR2A/19 & 17 & $2 / 0$ & 19 & - & 19 & - & 19 & - & 19 & - & 19 & - & 19 & - & 19 & - \\
\hline $\mathrm{APC} / 40$ & 40 & - & 33 & $1 / 6$ & 33 & $1 / 6$ & 35 & $0 / 5$ & 34 & $0 / 6$ & 33 & $0 / 7$ & 24 & $10 / 6$ & 24 & $12 / 4$ \\
\hline ARID1A/29 & 29 & - & 25 & $2 / 2$ & 27 & $2 / 0$ & 27 & $2 / 0$ & 26 & $2 / 1$ & 27 & $1 / 1$ & 26 & $3 / 0$ & 27 & $2 / 0$ \\
\hline ATM/59 & 52 & $7 / 0$ & 59 & - & 58 & $1 / 0$ & 59 & - & 59 & - & 59 & - & 59 & - & 59 & - \\
\hline BCORL1/20 & 19 & $0 / 1$ & 20 & - & 19 & $0 / 1$ & 19 & $0 / 1$ & 20 & - & 20 & - & 20 & - & 16 & $3 / 1$ \\
\hline BRCA1/52 & 51 & $1 / 0$ & 45 & $0 / 7$ & 36 & $0 / 16$ & 37 & $0 / 15$ & 48 & $0 / 4$ & 45 & $0 / 7$ & 51 & $1 / 0$ & 50 & $0 / 2$ \\
\hline BRCA2/19 & 19 & - & 18 & $1 / 0$ & 18 & $0 / 1$ & 18 & $0 / 1$ & 19 & - & 19 & - & 19 & - & 19 & - \\
\hline CALD1/57 & 53 & $3 / 0$ & 51 & $0 / 6$ & 51 & $0 / 6$ & 51 & $0 / 6$ & 55 & $0 / 2$ & 54 & $0 / 3$ & 54 & $1 / 2$ & 53 & $2 / 2$ \\
\hline CDKN2A/7 & 7 & - & 7 & - & 1 & $6 / 0$ & 1 & $6 / 0$ & 0 & $7 / 0$ & 0 & $7 / 0$ & 1 & $6 / 0$ & 0 & $7 / 0$ \\
\hline DISP2/18 & 18 & - & 16 & $1 / 1$ & 17 & $0 / 1$ & 17 & $0 / 1$ & 16 & $0 / 2$ & 16 & $0 / 2$ & 16 & $2 / 0$ & 16 & $0 / 2$ \\
\hline FBLN2/50 & 45 & $1 / 4$ & 38 & $3 / 9$ & 40 & $2 / 8$ & 39 & $4 / 7$ & 38 & $1 / 11$ & 37 & $1 / 12$ & 42 & $8 / 0$ & 42 & $4 / 4$ \\
\hline FBXW7/22 & 22 & - & 21 & $0 / 1$ & 22 & - & 22 & - & 22 & - & 22 & - & 20 & $2 / 0$ & 21 & $0 / 1$ \\
\hline HIVEP1/27 & 27 & - & 27 & - & 27 & - & 27 & - & 27 & - & 27 & - & 25 & $2 / 0$ & 26 & $0 / 1$ \\
\hline ITPR $3 / 50$ & 49 & $0 / 1$ & 44 & $0 / 6$ & 47 & $0 / 3$ & 46 & $0 / 4$ & 47 & $0 / 3$ & 47 & $0 / 3$ & 50 & - & 48 & $0 / 2$ \\
\hline JAG1/24 & 23 & $1 / 0$ & 24 & - & 24 & - & 24 & - & 24 & - & 24 & - & 23 & $1 / 0$ & 23 & $0 / 1$ \\
\hline KALRN/67 & 65 & $1 / 1$ & 62 & $0 / 5$ & 61 & $0 / 6$ & 53 & $0 / 14$ & 60 & $0 / 7$ & 54 & $0 / 13$ & 59 & $8 / 0$ & 63 & $0 / 4$ \\
\hline KDM6A/15 & 15 & - & 14 & $0 / 1$ & 15 & - & 15 & - & 14 & $0 / 1$ & 14 & $0 / 1$ & 14 & $1 / 0$ & 14 & $0 / 1$ \\
\hline KRAS/34 & 33 & $0 / 1$ & 31 & $0 / 3$ & 33 & $0 / 1$ & 33 & $0 / 1$ & 33 & $0 / 1$ & 33 & $0 / 1$ & 33 & $1 / 0$ & 33 & $0 / 1$ \\
\hline MACF1/87 & 81 & $2 / 4$ & 75 & $2 / 10$ & 79 & $0 / 8$ & 80 & $1 / 6$ & 82 & $0 / 5$ & 81 & $0 / 6$ & 77 & $8 / 2$ & 77 & $0 / 10$ \\
\hline MAP2K4/25 & 24 & $1 / 0$ & 25 & - & 25 & - & 25 & - & 25 & - & 25 & - & 20 & $4 / 1$ & 21 & $4 / 0$ \\
\hline MLL3/24 & 24 & - & 22 & $1 / 1$ & 22 & $1 / 1$ & 24 & - & 23 & $1 / 0$ & 23 & $0 / 1$ & 22 & $2 / 0$ & 22 & $2 / 0$ \\
\hline MYCBP2/19 & 17 & $2 / 0$ & 18 & $1 / 0$ & 19 & - & 19 & - & 19 & - & 19 & - & 18 & $0 / 1$ & 18 & $1 / 0$ \\
\hline NBEA/58 & 57 & $1 / 0$ & 51 & $3 / 4$ & 48 & $2 / 8$ & 48 & $0 / 10$ & 51 & $2 / 5$ & 53 & $2 / 3$ & 53 & $4 / 1$ & 52 & $6 / 0$ \\
\hline $\mathrm{NF} 2 / 19$ & 19 & - & 19 & - & 19 & - & 19 & - & 19 & - & 19 & - & 19 & - & 19 & - \\
\hline PBRM1/18 & 16 & $2 / 0$ & 18 & - & 18 & - & 18 & - & 18 & - & 18 & - & 18 & - & 15 & $2 / 1$ \\
\hline PLXNB2/45 & 45 & - & 33 & $1 / 11$ & 36 & $0 / 9$ & 36 & $0 / 9$ & 33 & $0 / 12$ & 33 & $0 / 12$ & 32 & $11 / 2$ & 33 & $2 / 10$ \\
\hline PTEN/63 & 63 & - & 62 & $0 / 1$ & 63 & - & 63 & - & 61 & $1 / 1$ & 61 & $1 / 1$ & 61 & $2 / 0$ & 61 & $1 / 1$ \\
\hline RBM10/29 & 28 & $0 / 1$ & 12 & $0 / 17$ & 29 & - & 29 & - & 29 & - & 27 & $2 / 0$ & 27 & $2 / 0$ & 29 & - \\
\hline RNF43/11 & 10 & $1 / 0$ & 8 & $0 / 3$ & 7 & $0 / 4$ & 7 & $0 / 4$ & 7 & $0 / 4$ & 7 & $0 / 4$ & 8 & $3 / 0$ & 8 & $0 / 3$ \\
\hline SDK2/68 & 63 & $0 / 5$ & 44 & $5 / 19$ & 53 & $5 / 10$ & 57 & $3 / 8$ & 63 & $0 / 5$ & 61 & $0 / 7$ & 53 & $12 / 3$ & 55 & $6 / 7$ \\
\hline SETD2/24 & 24 & - & 24 & - & 24 & - & 24 & - & 24 & - & 24 & - & 24 & - & 24 & - \\
\hline SF3B1/17 & 17 & - & 17 & - & 17 & - & 17 & - & 17 & - & 17 & - & 17 & - & 17 & - \\
\hline SIN3B/18 & 17 & $0 / 1$ & 17 & $0 / 1$ & 17 & $0 / 1$ & 17 & $0 / 1$ & 17 & $0 / 1$ & 16 & $0 / 2$ & 17 & $1 / 0$ & 17 & $0 / 1$ \\
\hline SMAD3/58 & 58 & - & 49 & $0 / 9$ & 53 & $0 / 5$ & 53 & $0 / 5$ & 51 & $0 / 7$ & 47 & $0 / 11$ & 53 & $5 / 0$ & 51 & $3 / 4$ \\
\hline SMAD4/15 & 11 & $1 / 3$ & 14 & $0 / 1$ & 14 & $0 / 1$ & 14 & $0 / 1$ & 15 & & 14 & $1 / 0$ & 14 & $1 / 0$ & 14 & $0 / 1$ \\
\hline SMARCA4/44 & 43 & $0 / 1$ & 42 & $0 / 2$ & 43 & $0 / 1$ & 43 & $0 / 1$ & 40 & $0 / 4$ & 40 & $0 / 4$ & 42 & $2 / 0$ & 42 & $0 / 2$ \\
\hline
\end{tabular}


Table 3: Continued

\begin{tabular}{lcccccccccccccccc} 
SPTB/33 & 32 & $0 / 1$ & 30 & $0 / 3$ & 29 & $0 / 4$ & 31 & $0 / 2$ & 30 & $0 / 3$ & 30 & $0 / 3$ & 30 & $2 / 1$ & 30 & $0 / 3$ \\
TGFBR1/10 & 8 & $2 / 0$ & 9 & $0 / 1$ & 9 & $0 / 1$ & 9 & $0 / 1$ & 9 & $0 / 1$ & 9 & $1 / 0$ & 8 & $2 / 0$ & 8 & $0 / 2$ \\
TGFBR2/37 & 36 & $1 / 0$ & 32 & $0 / 5$ & 34 & $0 / 3$ & 34 & $0 / 3$ & 33 & $0 / 4$ & 33 & $0 / 4$ & 31 & $6 / 0$ & 33 & $2 / 2$ \\
TLE4/16 & 15 & $0 / 1$ & 15 & $0 / 1$ & 16 & - & 16 & - & 16 & - & 16 & - & 15 & $0 / 1$ & 15 & $0 / 1$ \\
TP53/38 & 38 & - & 37 & $0 / 1$ & 38 & - & 38 & - & 38 & - & 37 & $0 / 1$ & 38 & - & 38 & - \\
TP53BP2/20 & 20 & - & 20 & - & 20 & - & 20 & - & 20 & - & 20 & - & 20 & - & 20 & - \\
$\mathrm{U} 2 \mathrm{AF} 1 / 20$ & 20 & - & 18 & $1 / 1$ & 19 & $1 / 0$ & 19 & $1 / 0$ & 20 & - & 20 & - & 18 & $2 / 0$ & 19 & $1 / 0$ \\
\hline \multirow{2}{*}{ Total / 1425} & 13 & 29 & 12 & 22 & 12 & 21 & 13 & 17 & 13 & 14 & 13 & 16 & 12 & 115 & 12 & 60 \\
& 70 & $/ 26$ & 65 & $/ 138$ & 99 & $/ 105$ & 02 & $/ 106$ & 21 & $/ 90$ & 00 & $/ 109$ & 90 & $/ 20$ & 91 & $/ 74$ \\
\hline
\end{tabular}

rates [34]. The success rate of the two models was $68 \%$ and $72 \%$, respectively, which confirmed that the technology used for PDOX and PDHX establishment is suitable. Of the 25 attempted trials, only four cases did not develop in either model, which was not related to any specific clinical characteristic. To compare the differences between the two models, four of the 13 cases in which both models were successfully established were randomly selected for detailed analysis.

Immunohistochemistry, including H\&E staining, showed that the basic phenotype of the original patient tumor was maintained in the PDOX and PDHX models. The molecular-genetic and metabolic pattern was also mostly maintained, as seen in the SNP, DNA methylation microarrays and metabolic analysis.

In this study, the majority of the moleculargenetic characteristics of the original patient tumors are maintained in the PDOX and PDHX models. Although several reports have shown that PDX models can reflect the molecular and genetic characteristics of original patient tumors, the key novelty of the present study is that PDOX and PDHX models were compared to each other and the original patient tumor simultaneously for the first time [34-36]. Many metabolites were maintained in the PDOX and PDHX models with respect to the original patient tumor, confirming the possibility of conducting accurate metabolic analysis of human tumors using PDX models.

The most important point of this study is that major characteristics of gene expression, SNP pattern, DNA methylation, as well as metabolism of the original patient tumors are maintained in the PDOX and PDHX models. It is well known that PDOX models reflect the metastatic pattern of the original patient and PDHX models do not metastasize $[1,2,16]$. A specific tumor microenvironment (TME) may therefore have a great influence on metastasis, rendering the subcutaneous site metastatic resistant [37]. The relationship of DNA hypermethylation and metastasis will be a subject of future experiments.

Previously-developed concepts and strategies of highly-selective tumor targeting can take advantage of molecular targeting of tumors, including tissue-selective therapy which focuses on unique differences between normal and tumor tissues [38-43].

\section{MATERIALS AND METHODS}

\section{Enrolled patients and clinical information}

Twenty-five patients who underwent surgery for pancreatic cancer at Asan Medical Center between February 2015 and June 2016 were included in the study. The surgical specimens were obtained with informed consent from the patients and under permission from the Institutional Review Board (IRB) of Asan Medical Center (No. 2015-0480). A retrospective medical record review was performed to obtain patient-, surgery-, and oncology-related data. The surgical procedure was determined according to the location of the tumor. Either pylorus-preserving or classic pancreatico-duodenectomy was performed to resect tumors of the head or uncinate of the pancreas. Distal pancreatectomy with splenectomy was performed on lesions in the pancreatic body or tail. Oncology-related factors included tumor size, T stage, tumor differentiation, lymphnode metastasis, and genetic alteration of $\mathrm{p} 53$, receptor tyrosine-protein kinase erbB2 (C-erbB-2), or deleted in pancreatic carcinoma locus 4 (DPC4). The surgical specimens and data used in this study were provided by Asan Bio-Resource Center, Korea Biobank Network (2016-3(115)).

\section{Tumor implantation and passaging in mice}

The animal care protocol for this study was approved by the International Animal-Care and Use Committee (IACUC) of the Laboratory of Animal Research at Asan Medical Center, Seoul, Korea. Five-week-old male NOD/ SCID (NSG) mice were used for tumor engraftment and were grown in a specific pathogen-free facility. The fresh tumor tissues obtained from pancreatic cancer patients who underwent surgery were immediately placed in RPMI medium (10\% FBS, $1 \%$ penicillin/streptomycin) at $4^{\circ} \mathrm{C}$ in a refrigerator. As soon as possible after this, the tumors were mechanically minced into small fragments $\left(1-2 \mathrm{~mm}^{3}\right)$. 
The fragments were implanted subcutaneously in the flank of the mouse for the heterotopic (PDHX) xenograft and on the pancreas for the orthotopic PDOX model [4]. All of the animals were anesthetized with $15 \mathrm{mg} / \mathrm{kg}$ Zoletil $^{\circledR}$ (Virbac, USA) and $2.5 \mathrm{mg} / \mathrm{kg}$ Rompun $^{\circledR}$ (Bayer Korea, Korea) by intraperitoneal injection, for tumor implantation. Following implantation, the mice were monitored twice a week for at least 12 months. Once the xenograft tumor had attained a size of $300-500 \mathrm{~mm}^{2}$, the tumor was excised and the mice were euthanized following the protocol of the Laboratory of Animal Research at Asan Medical Center. Part of the tumor that had been excised from the mouse was then engrafted into other NSG mice for expansion, while the residual part of the tumor was cryopreserved in a freezing medium with dimethyl sulfoxide and stored in liquid nitrogen.

\section{Immunohistochemical staining}

Tumors were fixed in $10 \%$ formalin for at least $24 \mathrm{~h}$ and then embedded in paraffin. Both the original patient tumor and mouse-grown tumor tissues were sectioned at $5-\mu \mathrm{m}$ thickness and stained with hematoxylin and eosin (H\&E). Immunohistochemistry was performed to examine the expression levels of p53 and DPC4 in the original patient tumors and in the tumors grown in the PDOX and PDHX models following the protocol of the Department of Diagnostic Pathology at the Asan Medical Center as previously described [44]. In brief, after deparaffinization and antigen retrieval, the slides were labeled with a monoclonal antibody against p53 (clone DO-7, 1:3,000; Dako, Glostrup, Denmark) and DPC4 (clone EP618Y,
A

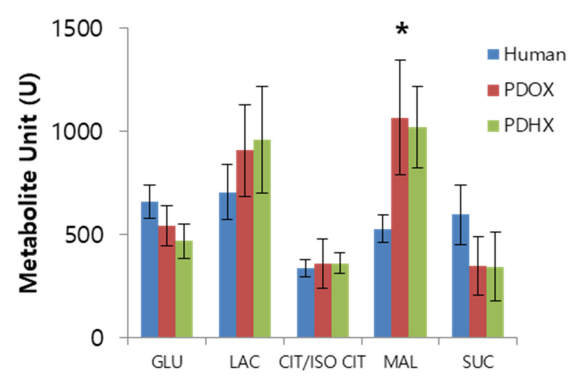

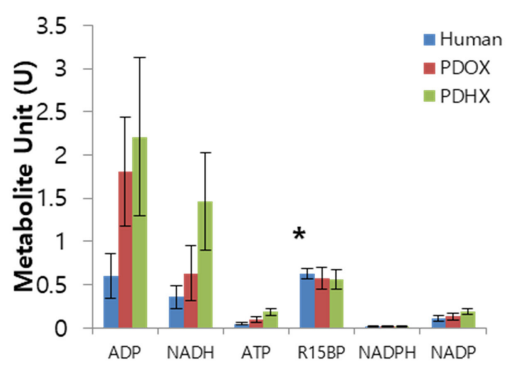

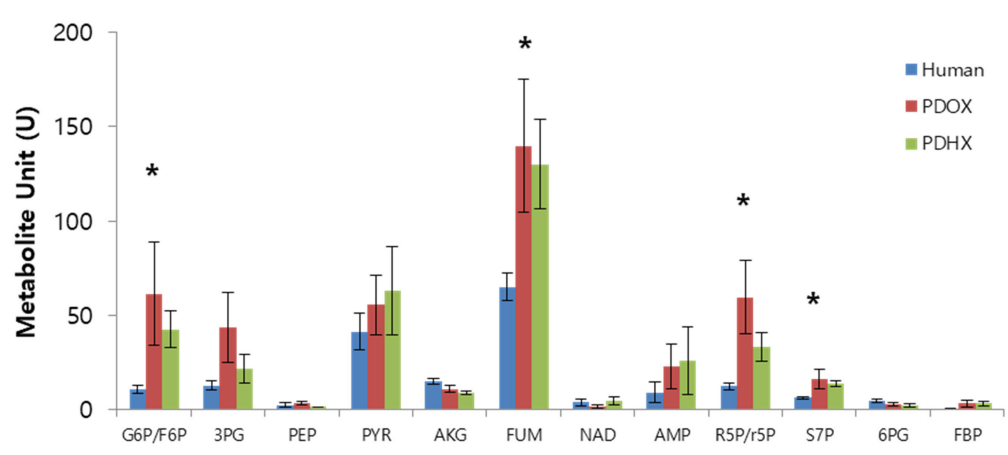

B

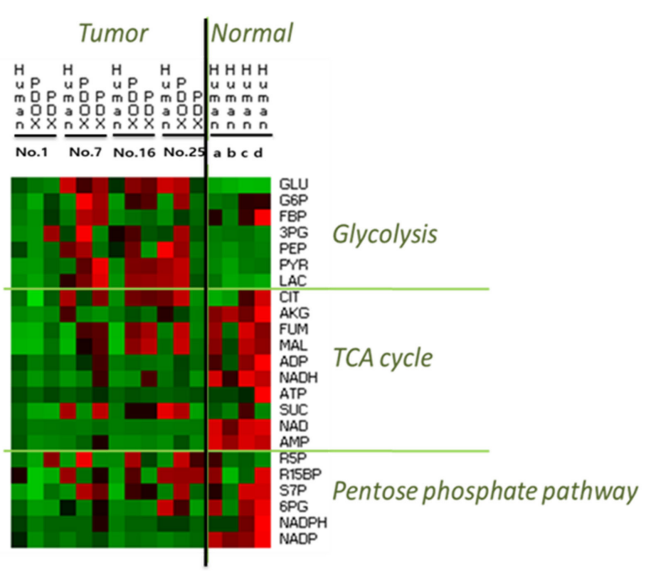

C

\begin{tabular}{|c|c|c|c|}
\hline & & \multicolumn{2}{|c|}{ human vs PDOX } \\
\hline & & $P>0.05$ & $P<0.05$ \\
\hline \multirow{2}{*}{$\begin{array}{c}\text { human } \\
\text { vs } \\
\text { PDHX }\end{array}$} & $P>0.05$ & $\begin{array}{l}\text { PYR, LAC, GLU, PEP, NAD, } \\
\text { CIT/ISO CIT, ADP, SUC, } \\
\text { AMP, R15BP, 6PG, } \\
\text { NADPH, NADP }\end{array}$ & $3 P G$ \\
\hline & $P<0.05$ & FBP, AKG, NADH, ATP & $\begin{array}{c}\text { G6P/F6P, FUM, MAL } \\
\text { R5P/r5P, S7P }\end{array}$ \\
\hline
\end{tabular}

Figure 4: Comparative analysis of metabolite profiling between original patient tumors and PDOX and PDHX tumors. (A) Quantitative comparison of 23 metabolites in the original patient tumor, PDOX, and PDHX tumor tissues. ( $p<0.05)$ (B) Heatmap analysis of metabolites in original patient normal or tumor tissues and PDOX/PDHX tumors. (C) Statistical analysis of PDOX and PDHX metabolites, based on the human-metabolite results. 
1:100; GeneTex, Irvine, CA, USA). Labeling was detected using the avidin-biotin complex staining method. 3,3'-Diaminobenzidine was used as the chromogen for p53, and 3-amino-9-ethylcarbazole was used for detecting DPC4. A pathologist who was experienced in pancreatic cancer reviewed the slides to compare the tumor architecture and desmoplastic appearance in the patient and PDX models.

\section{Single nucleotide polymorphism (SNP) microarray}

An Illumina HumanOmni 2.5M BeadChip, containing 2,500,000 SNPs, was used for whole-genome SNP genotyping. Genomic DNA (200 ng) was denatured with $0.1 \mathrm{~N} \mathrm{NaOH}$. Whole-genome amplification was carried out with a random primers mix using a Multi-Sample Master Mix. The amplified DNA was enzymatically fragmented using a Fragmentation Mix followed by precipitation using a Precipitation Mix 1 and 2-propanol. Hybridization of fragmented DNA to BeadChip was performed by denaturing the sample and dispensing $35 \mu$ of the sample onto the BeadChip section followed by incubation for $18 \mathrm{~h}$ at $48^{\circ} \mathrm{C}$ in a hybridization oven. BeadChips were washed, and the staining was performed following single-base extension. This reaction incorporates labeled nucleotides into the extended primers. Genotyping was performed using the Infinium assay on an Illumina GenomeStudio.

\section{Methylation microarray}

The Infinium Human-Methylation450K (HM450K) platform consisting of over 450,000 CpG sites was used to analyze methylation status. In brief, $4 \mu \mathrm{l}$ of bisulfiteconverted DNA ( 150 ng) was used in the whole-genome amplification reaction. After amplification, the DNA was fragmented enzymatically, precipitated, and re-suspended in hybridization buffer. All subsequent steps were performed following the standard Infinium protocol. The fragmented DNA was dispensed onto Human Methylation 450 BeadChips and hybridization was performed in a hybridization oven for $20 \mathrm{~h}$. After hybridization, the array was processed through primer extension and an immunohistochemistry-staining protocol to allow for detection of a single-base extension reaction.

\section{Metabolomics}

Standard metabolites and internal standards were purchased from Sigma-Aldrich. All solvents, including water, were purchased from J. T. Baker. The tissue (10-50 mg) was homogenized using a TissueLyzer (Qiagen) with $400 \mu \mathrm{l}$ chloroform/methanol (2/1). The homogenate was incubated for $20 \mathrm{~min}$ at $4^{\circ} \mathrm{C}$. Glutamine$13 \mathrm{C} 5$, the internal standard, was added to the sample after incubation and mixed well. The sample was then centrifuged at $13000 \mathrm{rpm}$ for $10 \mathrm{~min}$. The supernatant was collected and $100 \mu \mathrm{H}_{2} \mathrm{O}$ was added. The sample was mixed vigorously and centrifuged at $4000 \mathrm{rpm}$ for $20 \mathrm{~min}$, and the upper phase was taken and dried under vacuum. The dried sample was stored at $-20^{\circ} \mathrm{C}$ and reconstituted with $40 \mu \mathrm{l} \mathrm{H}_{2} \mathrm{O} /$ acetonitrile $(50 / 50 \mathrm{v} / \mathrm{v})$ prior to liquid chromatography-tandem mass spectrometry (LC-MS/ MS) analysis. Metabolites were analyzed with an LCMS/MS system equipped with a 1290 high-performance liquid chromatography (Agilent), Qtrap 5500 (ABSciex), and reverse-phase column (Synergi fusion RP $50 \times 2 \mathrm{~mm}$ ). Three $\mu$ of the sample was injected into the LC-MS/MS system and ionized with a turbo spray ionization source. Ammonium acetate $(5 \mathrm{mM})$ in $\mathrm{H}_{2} \mathrm{O}$ and ammonium acetate $(5 \mathrm{mM})$ in acetonitrile were used as mobile phase $\mathrm{A}$ and $\mathrm{B}$, respectively. The separation gradient was as follows: hold at $0 \% \mathrm{~B}$ for $5 \mathrm{~min}$; 0-90 \% B for $2 \mathrm{~min}$; hold at $90 \%$ for $8 \mathrm{~min}$; $90-0 \% \mathrm{~B}$ for $1 \mathrm{~min}$; then hold at $0 \% \mathrm{~B}$ for $9 \mathrm{~min}$. The LC flow rate was $70 \mu \mathrm{l} / \mathrm{min}$, except between $7-15 \mathrm{~min}$ when it was $140 \mu \mathrm{l} / \mathrm{min}$, and the column temperature was maintained at $23^{\circ} \mathrm{C}$. Multiple reaction monitoring was used in negative-ion mode, and the extracted ion chromatogram (EIC) corresponding to the specific transition for each metabolite was used for quantitation. The area under the curve of the EIC was normalized to that of the EIC of the internal standard, and the obtained ratio was used for quantitative comparison.

\section{Statistical analysis}

Statistical analyses were conducted using SPSS for Windows, version 21.0 (IBM Corp., Armonk, NY, USA). The Student's $t$-test or chi-square test was applied depending on the purpose of comparison. $P$-values less than 0.05 were considered statistically significant.

\section{Abbreviations}

PDX: patient-derived xenograft; PDOX; patientderivedorthotopic xenograft; PDHX: patient derived heterotopic xenograft; NSG: NOD scid gamma; SNP: single nucleotide polymorphism; C-erbB-2: receptor tyrosine-protein kinase erbB-2; DPC4: deleted in pancreatic carcinoma locus 4; NAD: nicotinamide adenine dinucleotide; NADP; nicotinamide adenine dinucleotide phosphate; NADH: reduced nicotinamide adenine dinucleotide; NADPH: reduced nicotinamide adenine dinucleotide phosphate; G6P: glucose-6-phosphate; CIT/ ISO CIT: citrate / isocitrate; AKG: alpha ketoglutarate; FUM: fumarate; MAL: malate; FBP: Fructose-1; 6-bisphosphate; AMP: adenosine monophosphate; ADP: adenosine diphosphate; ATP: adenosine triphosphate; 3PG: 3-phosphoglycerate; 6PG: 6-phosphogluconate; PYR: pyruvate; LAC: lactate; GLU: glucose; SUC: succinate; PEP:phosphoenolpyruvate; R5P/r5P: ribulose-5-phosphate / 
ribose-5-phosphate; R15BP: Ribose-1,5-bisphosphate; S7P: sedoheptulose-7-phosphate.

\section{Author contributions}

Study design, draft writing: ES.J, SC.K, R.M.H. Funding: SC.K; PDX generation, acquisition of tumor mass: JS.W, ES.J, MB.K; Immunohistochemistry: SM.H, SY.A; SNP microarray, DNA methylation microarray: ES.J, IK.S; Metabolomics: HJ.Y; Data analysis and interpretation: SH.C, ES.J, SC.K, R.M.H.

\section{CONFLICTS OF INTEREST}

The authors declare no conflicts of interest related to this work.

\section{FUNDING}

This study was supported by a grant from the Korean Health Technology R\&D Project, Ministry of Health \& Welfare, Republic of Korea (No. HI14C2640) and the Industrial Core Technology Development Program (10049112), Ministry of Trade, Industry \& Energy (MOTIE, Korea).

\section{REFERENCES}

1. Hoffman RM. Patient-derived orthotopic xenografts: better mimic of metastasis than subcutaneous xenografts. Nature Reviews Cancer. 2015; 15:451-452.

2. Hoffman RM, ed. In: Patient-Derived Mouse Models of Cancer. Hoffman RM, ed. Molecular and Translational Medicine. Series eds, Coleman WB, Tsongalis GJ. Issn. 2017; 2197-7852.

3. Hiroshima Y, Zhang Y, Murakami T, Maawy A, Miwa S, Yamamoto M, Yano S, Sato S, Momiyama M, Mori R, Matsuyama R, Chishima T, Tanaka K, et al. Efficacy of tumor-targeting Salmonella typhimurium A1-R in combination with anti-angiogenesis therapy on a pancreatic cancer patient-derived orthotopic xenograph (PDOX) and cell line mouse models. Oncotarget. 2014; 5:12346-12357. https://doi.org/10.18632/oncotarget.2641.

4. Fu X, Guadagni F, Hoffman RM. A metastatic nudemouse model of human pancreatic cancer constructed orthotopically with histologically intact patient specimens. Proc Natl Acad Sci USA. 1992; 89:5645-5649.

5. Hiroshima Y, Maawy A, Zhang Y, Murakami T, Momiyama M, Mori R, Matsuyama R, Katz MH, Fleming JB, Chishima T, Tanaka K, Ichikawa Y, Endo I, et al. Metastatic recurrence in a pancreatic cancer patient derived orthotopic xenograft (PDOX) nude mouse model is inhibited by neoadjuvant chemotherapy in combination with fluorescence-guided surgery with an anti-CA 19-9-conjugated fluorophore. Plos one. 2014; 9:e114310.
6. Hiroshima Y, Maawy AA, Katz MH, Fleming JB, Bouvet M, Endo I, Hoffman RM. Selective efficacy of zoledronic acid on metastasis in a patient-derived orthotopic xenograph (PDOX) nude-mouse model of human pancreatic cancer. J Surg Oncol. 2015; 111:311-315.

7. Kawaguchi K, Igarashi K, Murakami T, Kiyuna T, Lwin T, Hwang HK, DeLong J, Clary B, Bouvet M, Unno M, Hoffman RM. MEK inhibitors cobimetinib and trametinib, regressed a gemcitabine-resistant pancreatic cancer patientderived orthotopic xenograft (PDOX). Oncotarget. 2017; 8:47490-47496. https://doi.org/10.18632/oncotarget.17667.

8. Fu X, Le P, Hoffma RM. A metastatic-orthotopic transplant nude-mouse model of human patient breast cancer. Anticancer Res. 1993; 13:901-904.

9. $\mathrm{Fu} \mathrm{X,} \mathrm{Hoffman} \mathrm{RM.} \mathrm{Human} \mathrm{ovarian} \mathrm{carcinoma}$ metastatic models constructed in nude mice by orthotopic transplantation of histologically-intact patient specimens. Anticancer Res. 1993; 13:283-286.

10. Wang X, Fu X, Hoffman RM. A new patient-like metastatic model of human lung cancer constructed orthotopically with intact tissue via thoracotomy in immunodeficient mice. Int J Cancer. 1992; 51:992-995.

11. Hiroshima Y, Zhang Y, Zhang N, Maawy A, Mii S, Yamamoto M, Uehara F, Miwa S, Yano S, Murakami T, Momiyama M, Chishima T, Tanaka K, et al. Establishment of a patient-derived orthotopic xenograph (PDOX) model of HER-2-positive cervical cancer expressing the clinical metastatic pattern. Plos one. 2015; 10:e0117417.

12. Murakami T, Kiyuna T, Kawaguchi K, Igarashi K, Singh AS, Hiroshima Y, Zhang Y, Zhao M, Miyake K, Nelson SD, Dry SM, Li Y, DeLong JC, et al. The irony of highlyeffective bacterial therapy of a patient-derived orthotopic xenograft (PDOX) model of Ewing's sarcoma, which was blocked by Ewing himself 80 years ago. Cell Cycle. 2017; 16:1046-1052.

13. Fu X, Besterman JM, Monosov A, Hoffman RM. Models of human metastatic colon cancer in nude mice orthotopically constructed by using histologically intact patient specimens. Proc Natl Acad Sci USA. 1991; 88:9345-9349.

14. Metildi CA, Kaushal S, Luiken GA, Talamini MA, Hoffman RM, Bouvet M. Fluorescently-labeled chimeric anti-CEA antibody improves detection and resection of human colon cancer in a patient-derived orthotopic xenograft (PDOX) nude mouse model. J Surg Oncol. 2014; 109:451-458.

15. Hiroshima Y, Maawy A, Metildi CA, Zhang Y, Uehara F, Miwa S, Yano S, Sato S, Murakami T, Momiyama M, Chishima T, Tanaka K, Bouvet M, et al. Successful fluorescence-guided surgery on human colon cancer patient-derived orthotopic xenograft mouse models using a fluorophore-conjugated anti-CEA antibody and a portable imaging system. J Laparoendosc Adv Surg Tech A. 2014; 24:241-247.

16. Furukawa T, Kubota T, Watanabe M, Kitajima M, Hoffman RM. Orthotopic transplantation of histologically intact clinical specimens of stomach cancer to nude mice: 
correlation of metastatic sites in mouse and individual patient donors. Int J Cancer. 1993; 53:608-612.

17. Murakami T, Singh AS, Kiyuna T, Dry SM, Li Y, James AW, Igarashi K, Kawaguchi K, DeLong JC, Zhang Y, Hiroshima Y, Russell T, Eckardt MA, et al. Effective molecular targeting of CDK4/6 and IGF-1R in a rare FUS-ERG fusion CDKN2Adeletion doxorubicin-resistant Ewing's sarcoma patientderived orthotopic xenograft (PDOX) nude-mouse model. Oncotarget. 2016; 7:47556-47564. https://doi.org/10.18632/ oncotarget.9879.

18. Murakami T, DeLong J, Eilber FC, Zhao M, Zhang Y, Zhang N, Singh A, Russell T, Deng S, Reynoso J, Quan C, Hiroshima Y, Matsuyama R, et al. Tumor-targeting Salmonella typhimurium A1-R in combination with doxorubicin eradicate soft tissue sarcoma in a patientderived orthotopic xenograft PDOX model. Oncotarget. 2016; 7:12783-12790. https://doi.org/10.18632/ oncotarget. 7226 .

19. Hiroshima Y, Zhao M, Zhang Y, Zhang N, Maawy A, Murakami T, Mii S, Uehara F, Yamamoto M, Miwa S, Yano S, Momiyama M, Mori R, et al. Tumor-targeting Salmonella typhimurium A1-R arrests a chemo-resistant patient softtissue sarcoma in nude mice. PLoS One. 2015; 10:e0134324.

20. Kiyuna T, Murakami T, Tome Y, Kawaguchi K, Igarashi K, Zhang Y, Zhao M, Li Y, Bouvet M, Kanaya F, Singh A, Dry S, Eilber FC, et al. High efficacy of tumor-targeting Salmonella typhimurium A1-R on a doxorubicin- and dactolisib-resistant follicular dendritic-cell sarcoma in a patient-derived orthotopic xenograft PDOX nude mouse model. Oncotarget. 2016; 7:33046-33054. https://doi. org/10.18632/oncotarget.8848.

21. Hiroshima Y, Zhang Y, Zhang N, Uehara F, Maawy A, Murakami T, Mii S, Yamamoto M, Miwa S, Yano S, Momiyama M, Mori R, Matsuyama R, et al. Patient-derived orthotopic xenograft (PDOX) nude mouse model of softtissue sarcoma more closely mimics the patient behavior in contrast to the subcutaneous ectopic model. Anticancer Res. 2015; 35:697-701.

22. Kawaguchi K, Igarashi K, Murakami T, Kiyuna T, Nelson SD, Dry SM, Li Y, Russell TA, Singh AS, Chmielowski B, Unno M, Eilber FC, Hoffman RM. Combination of gemcitabine and docetaxel regresses both gastric leiomyosarcoma proliferation and invasion in an imageable patient-derived orthotopic xenograft (iPDOX) model. Cell Cycle. 2017; 16:1063-1069.

23. Igarashi K, Kawaguchi K, Murakami T, Kiyuna T, Miyake K, Nelson SD, Dry SM, Li Y, Yanagawa J, Russell TA, Singh A, Yamamoto N, Hayashi K, et al. Intra-arterial administration of tumor-targeting Salmonella typhimurium A1-R regresses a cisplatin-resistant relapsed osteosarcoma in a patient-derived orthotopic xenograft (PDOX) mouse model. Cell Cycle. 2017; 16:1164-1170.

24. Murakami T, Igarashi K, Kawaguchi K, Kiyuna T, Zhang Y, Zhao M, Hiroshima Y, Nelson SD, Dry SM, Li Y, Yanagawa J, Russell T, Federman N, et al. Tumor-targeting
Salmonella typhimurium A1-R regresses an osteosarcoma in a patient-derived xenograft model resistant to a moleculartargeting drug. Oncotarget. 2017; 8:8035-8042. https://doi. org/10.18632/oncotarget.14040.

25. Igarashi K, Kawaguchi K, Kiyuna T, Murakami T, Miwa S, Nelson SD, Dry SM, Li Y, Singh A, Kimura H, Hayashi $\mathrm{K}$, Yamamoto N, Tsuchiya $\mathrm{H}$, et al. Patient-derived orthotopic xenograft (PDOX) mouse model of adult rhabdomyosarcoma invades and recurs after resection in contrast to the subcutaneous ectopic model. Cell Cycle. 2017; 16:91-94.

26. Igarashi K, Kawaguchi K, Murakami T, Kiyuna T, Miyake K, Singh A, Nelson SD, Dry SM, Li Y, Yamamoto N, Hayashi K, Kimura H, Miwa S, et al. High efficacy of pazopanib on an undifferentiated spindle-cell sarcoma resistant to first-line therapy is identified with a patientderived orthotopic xenograft (PDOX) nude mouse model. J Cell Biochem. 2017; 118:2739-2743.

27. Igarashi K, Kawaguchi K, Kiyuna T, Murakami T, Miwa S, Nelson SD, Dry SM, Li Y, Singh A, Kimura H, Hayashi K, Yamamoto N, Tsuchiya H, et al. Temozolomide combined with irinotecan cuased regression in an adult pleomorphic rhabdomyosarcoma patient-derived orthotopic xenograft (PDOX) nude-mouse model. Oncotarget. 2017; 8:7587475880. https://doi.org/10.18632/oncotarget.16548.

28. Murakami T, Li S, Han Q, Tan Y, Kiyuna T, Igarashi K, Kawaguchi K, Hwang HK, Miyaki K, Singh AS, Nelson SD, Dry SM, Li Y, et al. Recombinant methioninase effectively targets a Ewing's sarcoma in a patient-derived orthotopic xenograft (PDOX) nude-mouse model. Oncotarget. 2017; 8:35630-35638. https://doi.org/10.18632/oncotarget.15823.

29. Yamamoto M, Zhao M, Hiroshima Y, Zhang Y, Shurell E, Eilber FC, Bouvet M, Noda M, Hoffman RM. Efficacy of tumor-targeting Salmonella typhimurium A1-R on a melanoma patient-derived orthotopic xenograft (PDOX) nude-mouse model. PLoS One. 2016; 11:e0160882.

30. Kawaguchi K, Murakami T, Chmielowski B, Igarashi K, Kiyuna T, Unno M, Nelson SD, Russell TA, Dry SM, Li Y, Eilber FC, Hoffman RM. Vemurafenib-resistant BRAFV600E mutated melanoma is regressed by MEK targeting drug trametinib, but not cobimetinib in a patient-derived orthotopic xenograft (PDOX) mouse model. Oncotarget. 2016; 7:71737-71743. https://doi.org/10.18632/ oncotarget. 12328 .

31. Kawaguchi K, Igarashi K, Murakami T, Chmiewloski B, Kiyuna T, Zhao M, Zhang Y, Singh A, Unno M, Nelson SD, Russell T, Dry SM, Li Y, et al. Tumor-targeting Salmonella typhimurium A1-R combined with Temozolomide regresses malignant melanoma with a BRAF-V600 mutation in a patient-derived orthotopic xenograft (PDOX) model. Oncotarget. 2016; 7:85929-85936. https://doi.org/10.18632/ oncotarget.13231.

32. Kawaguchi K, Igarashi K, Murakami T, Kiyuna T, Zhao M, Zhang Y, Nelson SD, Russell TA, Dry SM, Singh AS, Chmielowski B, Li Y, Unno M, et al. Salmonella typhimurium 
A1-R targeting of a chemotherapy resistant BRAF-V600E melanoma in a patient-derived orthotopic xenograft (PDOX) model is enhanced in combination with either vemurafenib or temozlomide. Cell Cycle. 2017; 16:1288-1294.

33. Kawaguchi K, Igarashi K, Murakami T, Zhao M, Zhang Y, Chmielowski B, Kiyuna T, Nelson SD, Russell TA, Dry SM, Li Y, Unno M, Eilber FC, et al. Tumor-targeting Salmonella typhimurium A1-R sensitizes melanoma with a BRAF-V600E mutation to vemurafenib in a patient-derived orthotopic xenograft (PDOX) nude mouse model. J Cell Biochem. 2017; 118:2314-2319.

34. Jun E, Jung J, Jeong SY, Choi EK, Kim MB, Lee JS, Hong SM, Seol HS, Hwang C, Hoffman RM, Shim IK, Chang S, Kim SC. Surgical and oncological factors affecting the successful engraftment of patient-derived xenografts in pancreatic ductal adenocarcinoma. Anticancer Res. 2016; 36:517-521.

35. Hoover M, Adamian Y, Brown M, Maawy A, Chang A, Lee J, Gharibi A, Katz MH, Fleming J, Hoffman RM, Bouvet M, Doebler R, Kelber JA. A novel method for RNA extraction from FFPE samples reveals significant differences in biomarker expression between orthotopic and subcutaneous pancreatic cancer patient-derived xenografts. Oncotarget. 2017; 8:5885-5894. https://doi.org/10.18632/ oncotarget.11809.

36. Bailey P, Chang DK, Nones K, Johns AL, Patch AM, Gingras MC, Miller DK, Christ AN, Bruxner TJ, Quinn MC, Nourse C, Murtaugh LC, Harliwong I, et al. Genomic analyses identify molecular subtypes of pancreatic cancer. Nature. 2016; 531:47-52.
37. Murata T, Mekada E, Hoffman RM. Reconstitution of a metastatic-resistant tumor microenvironment with cancerassociated fibroblasts enables metastasis. Cell Cycle. 2017; 16:533-535.

38. Blagosklonny MV. Matching targets for selective cancer therapy. Drug Discov Today. 2003; 8:1104-1107.

39. Blagosklonny MV. Teratogens as anti-cancer drugs. Cell Cycle. 2005; 4:1518-1521.

40. Blagosklonny MV. Treatment with inhibitors of caspases, that are substrates of drug transporters, selectively permits chemotherapy-induced apoptosis in multidrug-resistant cells but protects normal cells. Leukemia. 2001; 15:936-941.

41. Blagosklonny MV. Target for cancer therapy: proliferating cells or stem cells. Leukemia. 2006; 20:385-391.

42. Apontes P, Leontieva OV, Demidenko ZN, Li F, Blagosklonny MV. Exploring long-term protection of normal human fibroblasts and epithelial cells from chemotherapy in cell culture. Oncotarget. 2011; 2:222-233. https://doi.org/10.18632/oncotarget.248.

43. Blagosklonny MV. Tissue-selective therapy of cancer. Br J Cancer. 2003; 89:1147-1151.

44. Shin SH, Kim SC, Hong SM, Kim YH, Song KB, Park KM, Lee YJ. Genetic alterations of K-ras, p53, c-erbB-2, and DPC4 in pancreatic ductal adenocarcinoma and their correlation with patient survival. Pancreas. 2013; 42:216-22. 